\title{
PENGARUH PERSONAL SELLING TERHADAP KEPUTUSAN PEMBELIAN KACAMATA PADA AGUNG OPTIK DI KOTA PALU
}

\author{
TINI \\ MASKURI SUTOMO \\ IRA NURIYA SANTI \\ Program Studi S1 Manajemen, Fakultas Ekonomi, Universitas Tadulako \\ Email: Tini jikook9597@gmail.com,,Maskuri.sutomo@yahoo.com, Ira_nuria@yahoo.com
}

\begin{abstract}
The purpose of this study was to determine the effect of simultaneous and partial personal selling on the decision to buy glasses at Agung Optik in Palu city. The independent variable used in this study is personal selling $(X)$ while the dependent variable is the purchase decision $(Y)$. The research method used in this study is a descriptive causal sample method used in this study as many as 90 respondents with the form of sampling using purposive sampling technique. Data analysis method used in this study is a multiple linear regression analysis method. The results of this study indicate that: 1). Simultaneously personal selling has a significant influence on the decision to buy glasses at Agung Optik in Palu city. 2). Approach variables, presentation and demonstration, handling objections, closing, and follow-up partially have a significant effect on the decision to purchase glasses at Agung Optik in Palu city.
\end{abstract}

Keywords: Personal Selling, Purchase Decision.

\section{Abstrak}

Tujuan penelitian ini adalah untuk mengetahui pengaruh secara simultan dan parsial personal selling terhadap keputusan pembelian kacamata pada Agung Optik di kota Palu. Variabel independen yang digunakan dalam penelitian ini adalah personal selling $(\mathrm{X})$ sedangkan variabel dependen adalah keputusan pembelian (Y). Metode penelitian yang digunakan dalam penelitian ini adalah metode deskriptif kausal sampel yang digunakan pada penelitian ini yaitu sebanyak 90 responden dengan bentuk pengambilan sampel menggunakan teknik purposive sampling. Metode analisis data yang digunakan dalam penelitian ini adalah metode analisis regresi linear berganda. Hasil penelitian ini menunjukan bahwa : 1). Secara simultan personal selling berpengaruh secara signifikan terhadap keputusan pembelian kacamata pada Agung Optik di kota Palu. 2). Variabel pendekatan, presentasi dan demontasi, penanganan keberatan, menutup, dan tindak lanjut secara parsial berpengaruh signifikan terhadap keputusan pembelian kacamata pada Agung Optik di kota Palu.

Kata kunci: Personal Selling, Keputusan Pembelian.

\section{PENDAHULUAN}

Semakin pesatnya perkembangan teknologi khususnya benda-benda elektronik yang menggunakan layar monitor, setiap orang dituntut untuk mampu mengikuti perkembangan tersebut. Seringnya melihat layar monitor baik komputer, telepon seluler, maupun benda elektronik lainnya maka semakin lama akan berpengaruh terhadap daya penglihatan seseorang. Pada umumnya gangguan akut pada mata bisa diatasi dengan tindakan operasi, namun hal tersebut tentunya alan memakan biaya yang cukup besar, untuk menanggulangi hal tersebut maka mayoritas orang yang mengalami gangguan pada indera penglihatannya memilih jalur alternatif yaitu dengan menggunakan kacamata maupun lensa kontak.

Seiring perkembangan jaman, masyarakat saat ini khususnya remaja lebih menyukai pemakaian kacamata terlebih tidak hanya untuk fungsi membantu penglihatan melainkan juga dengan alasan mode, gaya, atau tren. Banyaknya permintaan konsumen akan kacamata semakin banyak pula dijumpai toko-toko dipinggir jalan raya atau gerai-gerai di dalam pusat pembelanjaan yang menjual kacamata atau sering disebut dengan istilah optik. 
Penggunaan kacamata bagi seseorang yang mengalami gangguan penglihatan merupakan salah satu penggunaan produk yang cukup rumit secara teknis karena tenaga penjual harus menjelaskan manfaat yang diperoleh oleh konsumen, menyesuaikan produk yang ditawarkan dengan kebutuhan yang sesuai dengan konsumen dan konsumen juga perlu mengetahui kacamata yang sesuai dengan kebutuhan penglihatannya agar tidak semakin memburuk daya penglihatan yang dialami.

Pada saat ini persaingan bisnis semakin ketat antara berbagai perusahaan dalam menghasilkan dan menjual produknya dan ini memberikan pengaruh terhadap pandangan bahwa perusahaan harus memberitahukan dan memperkenalkan produknya kepada masyarakat agar terdorong untuk membeli produk suatu perusahaan melalui kegiatan promosi. Strategi promosi dan pemasaran yang tepat akan membantu para pelaku bisnis dalam menghadapi persaingan. Menurut (Kotler \& Amstrong, 2012:464) personal selling adalah presentasi pribadi oleh wiraniaga perusahaan dengan tujuan melakukan penjualan dan membangun hubungan dengan pelanggan. Maka personal selling merupakan metode atau strategi promosi yang tepat untuk mencapai tujuan perusahaan dalam menghadapi persaingan bisnis.

Penerapan personal selling yang tepat dalam suatu perusahaan akan memberikan manfaat yang besar dalam memasarkan suatu produknya sehingga peran personal selling sangat penting untuk perusahaan karena pesan yang disampaikan individual dan dua arah sehingga tenaga penjual dapat memberikan informasi mengenai produk yang ditawarkan dan juga dapat mempengaruhi keputusan pembelian. Adanya personal selling diharapkan calon konsumen dapat mengenal lebih produk yang dihasilkan perusahaan dan pada akhirnya dapat menimbulkan ketertarikan akan produk yang ditawarkan oleh perusahaan. Semakin tinggi kunjungan yang dilakukan tenaga penjual pada konsumen, maka semakin tinggi kemungkinan produk yang terjual.

Semua transaksi yang dilakukan oleh tenaga penjual kepada konsumen merupakan suatu pekerjaan yang membutuhkan waktu yang tidak sedikit dan tentunya bukan hal yang mudah dilakukan para tenaga penjual dalam meningkatkan penjualan. Salah satu hubungan paling dekat dengan calon pelanggan adalah dengan personal selling, karena turunnya pendapatan perusahaan optik tergantung tenaga penjual dalam menjual produk kacamata.

\section{KAJIAN LITERATURE DAN PENGEMBANGAN HIPOTESIS}

Menurut Hermawan (2012:108) personal selling (penjualan personal) adalah komunikasi langsung (tatap muka) antara penjual dan calon pelanggan dan membentuk pemahaman pelanggan terhadap produk sehingga mereka kemudian akan mencoba dan membelinya.

Menurut Sitorus (2014:93) personal selling merupakan komunikasi dua arah dengan berhadapan muka, sehingga dapat menyampaikan pesan secara langsung tentang kelebihan ataupun kegunaan produk/jasa yang ditawarkan dan dapat menjawab pertanyaan calon konsumen pada saat itu juga.

Dimensi personal selling yang digunakan merupakan dimensi menurut Kotler dan Amstrong (2012) yaitu:

1. Approach (pendekatan).

2. Presentation and demonstration (presentasi dan demonstrasi).

3. Handling objections (penanganan keberatan).

4. Closing (menutup penjualan).

5. Follow up (tindak lanjut).

\section{Keputusan Pembelian}


Menurut Kotler dan Amstrong (2012:176) keputusan pembelian adalah keputusan konsumen mengenai preferensi atas merek-merek yang ada di dalam kumpulan pilihan. Proses keputusan pembelian konsumen terdiri dari lima langkah yaitu:

1. Mengenal kebutuhan.

2. Pencarian informasi.

3. Evaluasi alternatif.

4. Keputusan pembelian.

5. Perilaku setelah membeli.

\section{Kerangka Pemikiran}

Personal selling $(\mathrm{X})$

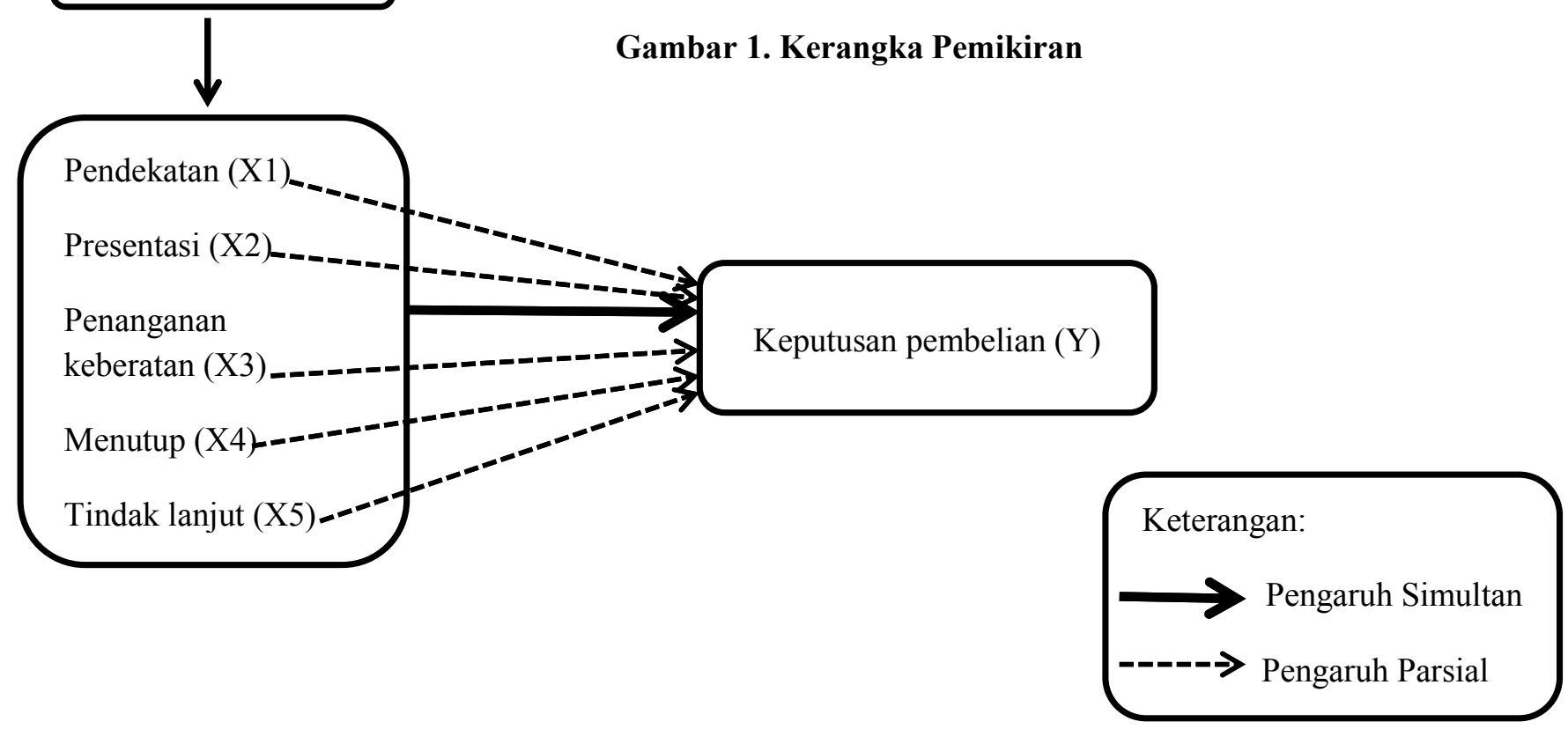

\section{Hipotesis}

Berdasarkan latar belakang dan kerangka pemikiran di atas, dugaan sementara yang diajukan oleh peneliti dalam penelitian ini atas masalah yang telah dirumuskan adalah sebagai berikut:

1. Personal selling secara simultan berpengaruh signifikan terhadap keputusan pembelian kacamata pada Agung Optik di Kota Palu.

2. Personal selling secara parsial berpengaruh signifikan terhadap keputusan pembelian kacamata pada Agung Optik di Kota Palu.

\section{METODE PENELITIAN}


Jenis penilitian ini adalah penelitian deskriptif dan kausal, menurut Sugiyono (2014:53) Penelitian deskriptif adalah rumusan masalah yang berkenaan dengan pernyataan terhadap keberadaan variabel mandiri, baik hanya satu variabel atau lebih. Adapun menurut Sugiyono (2012:38) Objek penelitian (variabel penelitian) adalah segala sesuatu yang berbentuk apa saja yang ditetapkan oleh peneliti untuk dipelajari sehingga informasi tentang hal tersebut, kemudian ditarik kesimpulannya. Objek dalam penelitian ini adalah pengaruh personal selling sebagai variabel yang memengaruhi (independen) sedangkan variabel yang dipengaruhi (dependen) ialah keputusan pembelian kacamata pada Agung Optik di Kota Palu.

Populasi adalah wilayah generalisasi yang terdiri dari objek atau subjek yang mempunyai kualitas dan karakteristik tertentu yang ditetapkan oleh peneliti untuk dipelajari dan kemudian ditarik kesimpulannya (Sugiyono,2015:119). Populasi dalam penelitian ini adalah semua konsumen yang membeli kacamata pada Agung Optik. Metode pengambilan sampel yang digunakan dalam penelitian ini adalah non-probability sampling dan menggunakan teknik purposive sampling yaitu teknik penentuan sampel dengan pertimbangan tertentu. Adapun kriteria-kriteria responden yang dijadikan sampel pada penelitian ini adalah sebagai berikut:

1. Bersedia mengisi kuesioner yang diberikan.

2. Minimal berusia 20 tahun.

3. Pengambil keputusan dalam membeli kacamata pada Agung Optik.

Jumlah sampel yang diambil untuk mewakili populasi dalam penelitian ini sebanyak 90 sampel. Penentuan sampel sebanyak 90 responden, ini didasarkan pada teori-teori Roscoe dalam Sugiyono (2016:102-103) bila dalam penelitian akan melakukan analisis dengan multivariate (korelasi atau regresi berganda misalnya), maka jumlah anggota sampel minimal 10 kali dari jumlah variabel yang diteliti (independen + dependen).

\section{Pengujian Instrumen Penelitian}

Sebelum data dikumpulkan dan diolah, maka sebelumnya peneliti perlu melakukan uji coba instrumen terlebih dahulu, guna menegetahui tingkat validitas dan reliabilitas suatu instrument.

\section{Uji Validitas}

Uji validitas bertujuan untuk menguji sejauh mana ketepatan alat pengukur dapat mengungkapkan konsep gejala/kejadian yang diukur. Instrument yang valid berarti alat ukur yang digunakan untuk mendapatkan data itu valid. Valid berarti instrumen tersebut dapat digunakan untuk mengukur apa yang seharusnya diukur (Sugiyono, 2014:203). Syarat minimum untuk dianggap memenuhi syarat adalah $\mathrm{r}=0.3$. Jadi, korelasi antara butir dengan skor total kurang dari 0.3 maka butir dalam instrument tersebut dinyatakan tidak valid. Sebaliknya, bila skor total sama dengan 0.3 atau lebih (paling kecil 0.3 ) maka instrumen tersebut dinyatakan valid (Sugiyono, 2014:188).

\section{Uji Reliabilitas}

Ghozali (2013:47) mengemukakan bahwa uji reliabilitas adalah alat untuk mengukur suatu kuesioner yang merupakan indikator dari variabel atau konstruk. Suatu kuesioner dikatakan reliabel atau handal jika jawaban seseorang terhadap pertanyaan adalah konsisten atau stabil dari waktu ke waktu. Pengujian pada penelitian ini mengukur reliabelnya suatu variabel dengan cara melihat Cronbach Alpha dengan signifikansi yang digunakan lebih besar dari 0.60. Suatu konstruk atau variabel dikatakan reliabel jika memberikan nilai Cronbach Alpha $>0.60$ (Ghozali, 2013:48).

\section{Metode Analisis}

1. Uji Normalitas 
Uji Normallitas digunakan untuk menguji apakah dalam sebuah model regresi variabel (pengganggu) dependen dan independen atau keduanya memiliki distribusi normal (Ghozali, 2013:160). Model regresi yang baik adalah distribusi data normal atau mendekati normal. Deteksi normalitas dilakukan dengan melihat penyebaran data (titik) pada sumbu diagonal dan grafik.

2. Uji Multikolinieritas

Uji Multikolinieritas digunakan untuk menguji apakah model regresi ditemukan adanya kolerasi antara variabel bebas independen. Model regresi yang baik seharusnya antara variabel independen tidak terjadi korelasi antara variabel independen (Ghozali, 2013:105).

3. Uji Heteroskedastisitas

Menurut Ghozali (2013:139) uji heteroskedastisitas yaitu untuk menguji apakah dalam model regresi terjadi ketidaksamaan variance dari residual satu pengamatan ke pengamatan yang lain. Jika variance dari residual satu pengamatan ke pengamatan lain tetap, maka disebut homoskedastisitas dan jika berbeda disebut heteroskedastisitas. Model regresi yang baik adalah tidak terjadi heteroskedastisitas.

4. Regresi Linear Berganda

Untuk menguji pengaruh variabel personal selling terhadap keputusan pembelian kacamata maka digunakan alat uji statistik yaitu regresi linear berganda yang dapat dirumuskan (Sugiyono, 2012:262):

$$
\mathbf{Y}=\mathbf{a}+\mathbf{b}_{1} \mathbf{X}_{1}+\mathbf{b}_{2} \mathbf{X}_{2}+\ldots \mathbf{e}
$$

Keterangan:

$$
\begin{array}{ll}
\mathrm{A} & =\text { Konstanta } \\
\mathrm{Y} & =\text { Keputusan Pembelian pada Agung Optik } \\
\mathrm{b}_{1}, \mathrm{~b}_{2}, \mathrm{~b}_{3} & =\text { Koefisien Regresi masing-masing Variabel } \\
\mathrm{X}_{1} & =\text { Pendekatan } \\
\mathrm{X}_{2} & =\text { Presentasi dan demontrasi } \\
\mathrm{X}_{3} & =\text { Penanganan keberatan } \\
\mathrm{X}_{4} & =\text { Menutup } \\
\mathrm{X}_{5} & =\text { Tindak lanjut } \\
\mathrm{E} & =\text { Term Error (Tingkat Kesalahan) }
\end{array}
$$

\section{HASIL DAN PEMBAHASAN}

Berikut ini adalah hasil uji validitas dan reliabilitas atas item pernyataan yang terdapat dalam kuesioner penelitian terhadap variabel personal selling (X1) dan keputusan pembelian (Y). Adapun hasilnya disajikan dalam tabel 1 berikut:

Tabel 1. Hasil Uji Validitas dan Reliabilitas Instrumen Penelitian

\begin{tabular}{cccccc}
\hline Variabel & Item & $\begin{array}{c}\text { Total } \\
\text { Correlation }\end{array}$ & Ket & $\begin{array}{c}\text { Cronbach } \\
\text { Alpha }\end{array}$ & Ket \\
\hline Pendekatan & X1.1 & 0,833 & Valid & & Reliabel \\
(X1) & X1.2 & 0,817 & Valid & 0,908 & \\
& X1.3 & 0,849 & Valid & & Reliabel \\
Presentasi dan & X2.1 & 0,839 & Valid & & \\
demonstrasi (X2) & X2.2 & 0,523 & Valid & 0,719 & \\
& X2.3 & 0,342 & Valid & & \\
\hline
\end{tabular}


JURNAL ILMU MANAJEMEN UNIVERSITAS TADULAKO

Vol. 5, No. 2, Mei 2019, p. 183 - 195

ISSN : 2443-3578 (On Line) / ISSN : 2443-1850 (Print)

\begin{tabular}{cccccc}
\hline Variabel & Item & $\begin{array}{c}\text { Total } \\
\text { Correlation }\end{array}$ & Ket & $\begin{array}{c}\text { Cronbach } \\
\text { Alpha }\end{array}$ & Ket \\
\hline \multirow{2}{*}{ Penanganan Keberatan } & X3.1 & 0,565 & Valid & & \\
(X3) & X3.2 & 0,341 & Valid & 0,626 & Reliabel \\
& X3.3 & 0,421 & Valid & & \\
Menutup (X4) & X4.1 & 0,857 & Valid & & Reliabel \\
& X4.2 & 0,824 & Valid & 0,940 & \\
\hline \multirow{2}{*}{ Xindak Lanjut (X5) } & X5.1 & 0,972 & Valid & & Reliabel \\
& X5.2 & 0,942 & Valid & & \\
\hline \multirow{2}{*}{ Keputusan Pembelian } & X5.3 & 0,898 & Valid & 0,969 & \\
(Y) & Y1.1 & 0,892 & Valid & & Reliabel
\end{tabular}

Sumber: Data diolah Tahun 2018

Berdasarkan hasil uji validitas dan reliabilitas diperoleh bahwa seluruh variabel memiliki koefisien Cronbach Alpha (a) lebih besar dari 0,60 sehingga berdasarkan syarat minimum reliabilitas lebih besar dari 0,60 maka seluruh variabel yang digunakan reliabel dan dapat digunakan dalam penelitian ini. Sedangkan uji validitas terhadap seluruh variabel juga menunjukan nilai koefisien korelasi yang lebih besar dari 0,30 sehingga item pernyataan yang ada valid untuk digunakan.

Penelitian ini menggunakan analisis regresi linear berganda dengan tujuan untuk menguji pengaruh personal selling terhadap keputusan pembelian. Untuk lebih jelasnya hasil analisis regresi linear berganda dapat dilihat pada tabel 2 berikut:

Tabel 2. Hasil Uji Regresi Linear Berganda

\begin{tabular}{|c|c|c|c|c|c|}
\hline \multicolumn{5}{|c|}{ Dependen Variabel Y = Keputusan Pembelian } \\
\hline \multirow{2}{*}{ Variabel Independen } & $\begin{array}{c}\text { Coefficients } \\
\text { Regression }\end{array}$ & $\begin{array}{c}\text { Standardized } \\
\text { Coefficients }\end{array}$ & Parsial & Sig t \\
\cline { 2 - 5 } & B & Beta & & \\
\cline { 2 - 5 }$($ Constant) & .691 & & 2.278 & .025 \\
\hline $\begin{array}{c}\text { X1 } \\
\text { (Pendekatan) }\end{array}$ & .307 & .292 & 5.823 & .000 \\
\hline $\begin{array}{c}\text { X2 } \\
\text { (Presentasi) }\end{array}$ & .730 & .711 & 8.220 & .000 \\
\hline $\begin{array}{c}\text { X3 } \\
\text { (Penanganan Keberatan) }\end{array}$ & .241 & .220 & 2.582 & .012 \\
\hline $\begin{array}{c}\text { X4 } \\
\text { (Menutup) }\end{array}$ & .315 & .310 & 4.676 & .000 \\
\hline $\begin{array}{c}\text { X5 } \\
\text { (Tindak Lanjut) }\end{array}$ & .453 & .464 & 5.630 & .000 \\
\hline
\end{tabular}


JURNAL ILMU MANAJEMEN UNIVERSITAS TADULAKO

Vol. 5, No. 2, Mei 2019, p. 183 - 195

ISSN : 2443-3578 (On Line) / ISSN : 2443-1850 (Print)

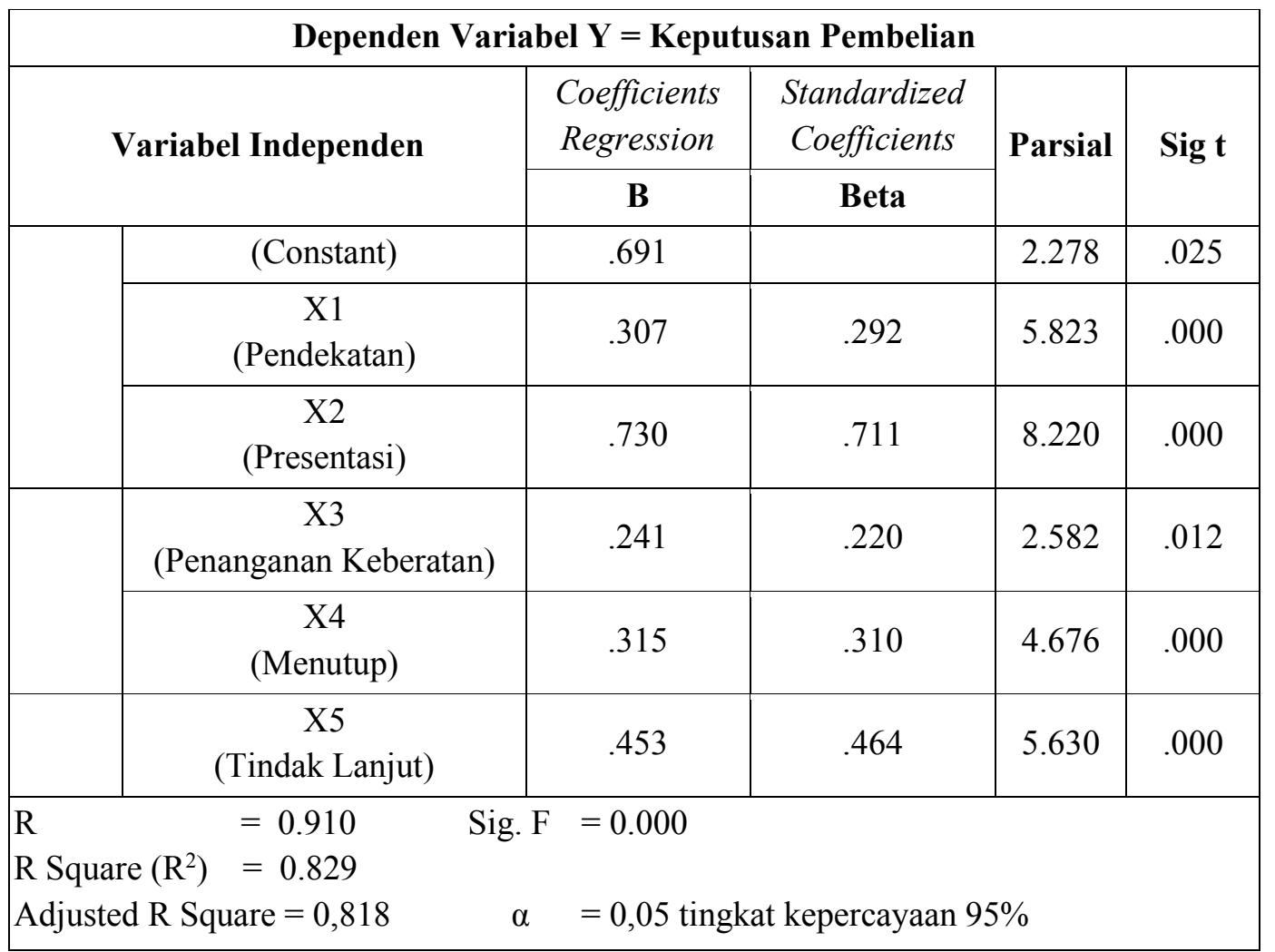

Sumber: Data diolah Tahun 2018

Berdasarkan tabel 2 tersebut, dapat ditulis dalam bentuk persamaan regresi linear berganda. Untuk lebih jelasnya bentuk persamaan tersebut dapat dilihat sebagai berikut:

$$
\mathrm{Y}=0.691+0.307 \mathrm{X}_{1}+0.730 \mathrm{X}_{2}+0.241 \mathrm{X}_{3}+0.315 \mathrm{X}_{4}+0.453 \mathrm{X}_{5} \mathrm{e}
$$

Berdasarkan penjabaran tersebut menunjukkan bahwa, variabel independen yang dianalisis yaitu variabel $\left(\mathrm{X}_{1}, \mathrm{X}_{2}, \mathrm{X}_{3}, \mathrm{X}_{4}, \mathrm{X}_{5}\right)$ memberikan pengaruh positif terhadap variabel dependen ( $\mathrm{Y}$ ), yaitu keputusan pembelian kacamata pada Agung Optik di Kota Palu. Untuk lebih jelasnya penjelasan bentuk persamaan tersebut dapat dilihat berikut ini:

1. Nilai Konstanta sebesar 0.691, artinya jika variabel (personal selling) bernilai 0, maka variabel dependen (keputusan pembelian kacamata pada Agung Optik di Kota Palu) nilainya sebesar 0.691.

2. Koefisien regresi dimensi pendekatan $\left(\mathrm{X}_{1}\right)$ sebesar 0.307 , artinya jika pendekatan naik satu satuan, maka keputusan pembelian kacamata pada Agung Optik di Kota Palu naik sebesar 0.307.

3. Koefisien regresi dimensi presentasi $\left(\mathrm{X}_{2}\right)$ sebesar 0.730 , artinya jika presentasi naik satu satuan, maka keputusan pembelian kacamata pada Agung Optik di Kota Palu naik sebesar 0.730.

4. Koefisien regresi dimensi penanganan keberatan $\left(\mathrm{X}_{3}\right)$ sebesar 0.241 , artinya jika penanganan keberatan naik satu satuan, maka keputusan pembelian kacamata pada Agung Optik di Kota Palu naik sebesar 0.241 .

5. Koefisien regresi dimensi menutup $\left(\mathrm{X}_{4}\right)$ sebesar 0.315 , artinya jika menutup naik satu satuan, maka keputusan pembelian kacamata pada Agung Optik di Kota Palu naik sebesar 0.315.

6. Koefisien regresi dimensi tindak lanjut $\left(\mathrm{X}_{5}\right)$ sebesar 0.453 , artinya jika tindak lanjut naik satu satuan, maka keputusan pembelian kacamata pada Agung Optik di Kota Palu naik sebesar 0.453.

Tahap selanjutnya adalah menguji signifikan hubungan atau uji $\mathrm{F}$ antara variabel penelitian yaitu personal selling $(\mathrm{X})$ terhadap keputusan pembelian (Y) dengan perhitungan menggunakan SPSS 16.0 dengan hasil sebagai berikut: 
Tabel 3. Hasil Uji F

ANOVA $^{\mathrm{b}}$

\begin{tabular}{|l|l|r|r|r|c|c|}
\hline \multicolumn{2}{|l|}{ Model } & \multicolumn{1}{|c|}{$\begin{array}{c}\text { Sum of } \\
\text { Squares }\end{array}$} & Df & Mean Square & F & Sig. \\
\hline \multirow{2}{*}{1} & Regression & 26.186 & 5 & 5.237 & 81.252 & $.000^{\mathrm{a}}$ \\
\cline { 2 - 7 } & Residual & 5.414 & 84 & .064 & & \\
\cline { 2 - 7 } & Total & 31.600 & 89 & & & \\
\hline
\end{tabular}

Sumber: Data diolah Tahun 2018

Berdasarkan tabel.3 di atas diperoleh Sig.F yaitu 0.000, artinya nilai tersebut lebih kecil dibandingkan dengan nilai yang disyaratkan yaitu $\alpha=0.05$ dengan tingkat kepercayaan $95 \%$. dengan demikian dapat dinyatakan bahwa secara simultan variabel personal selling secara simultan berpengaruh signifikan terhadap keputusan pembelian kacamata pada Agung Optik di Kota Palu.

Hasil Uji t adalah untuk mengetahui apakah variabel $\left(\mathrm{X}_{1}-\mathrm{X}_{5}\right)$ secara parsial berpengaruh terhadap $\mathrm{Y}$. Untuk lebih jelasnya hasil dapat dilihat pada tabel 4 berikut:

Tabel 4. Hasil Uji t

\begin{tabular}{|c|c|c|c|}
\hline \multicolumn{2}{|c|}{ Model } & t & Sig \\
\hline \multirow{4}{*}{} & (Constant) & 2.278 & .025 \\
\cline { 2 - 4 } & $\mathrm{X}_{1}$ & 5.823 & .000 \\
\cline { 2 - 4 } $\mathrm{X}_{2}$ & 8.220 & .000 \\
\hline $\mathrm{X}_{3}$ & 2.582 & .012 \\
\hline $\mathrm{X}_{4}$ & 4.676 & .000 \\
\cline { 2 - 4 } & $\mathrm{X}_{5}$ & 5.630 & .000 \\
\hline
\end{tabular}

Sumber: Data diolah Tahun 2018

Berdasarkan tabel 4 di atas hasil uji t pengujian variabel $\left(\mathrm{X}_{1}-\mathrm{X}_{5}\right)$ terhadap $\mathrm{Y}$ dijelaskan sebagai berikut:

\section{Hasil Pengujian Hipotesis $X_{1}$ terhadap $Y$}

Hipotesis kedua $\left(\mathrm{H}_{2}\right)$ adalah untuk mengetahui apakah pendekatan $\left(\mathrm{X}_{1}\right)$ secara parsial berpengaruh signifikan terhadap keputusan pembelian kacamata pada Agung Optik di Kota Palu. Berdasarkan tabel di atas menunjukkan bahwa pendekatan $\left(\mathrm{X}_{1}\right)$ memiliki nilai signifikan sebesar 0.000 . Artinya nilai tersebut $<$ dari taraf yang disyaratkan yaitu $\alpha=0.05$, maka dapat disimpulkan bahwa secara parsial pendekatan berpengaruh signifikan terhadap keputusan pembelian.

\section{Hasil Pengujian Hipotesis $X_{2}$ terhadap $Y$}

Hipotesis ketiga $\left(\mathrm{H}_{3}\right)$ adalah untuk mengetahui apakah presentasi dan demonstrasi $\left(\mathrm{X}_{2}\right)$ secara parsial berpengaruh signifikan terhadap keputusan pembelian kacamata pada Agung Optik di Kota Palu. Berdasarkan tabel di atas menunjukkan bahwa $\left(\mathrm{X}_{2}\right)$ memiliki nilai signifikan sebesar 0.000. Artinya nilai tersebut $<$ dari taraf yang disyaratkan yaitu $\alpha=0.05$, maka dapat disimpulkan bahwa secara parsial presentasi dan demonstrasi berpengaruh signifikan terhadap keputusan pembelian.

\section{Hasil Pengujian Hipotesis $X_{3}$ terhadap $Y$}

Hipotesis ketiga $\left(\mathrm{H}_{4}\right)$ adalah untuk mengetahui apakah penanganan keberatan $\left(\mathrm{X}_{3}\right)$ secara parsial berpengaruh signifikan terhadap keputusan pembelian kacamata pada Agung Optik di Kota Palu. Berdasarkan tabel di atas menunjukkan bahwa $\left(\mathrm{X}_{3}\right)$ memiliki nilai signifikan sebesar 0.012. Artinya 
nilai tersebut $<$ dari taraf yang disyaratkan yaitu $\alpha=0.05$, maka dapat disimpulkan bahwa secara parsial penanganan keberatan berpengaruh signifikan terhadap keputusan pembelian.

\section{Hasil Pengujian Hipotesis $X_{4}$ terhadap $Y$}

Hipotesis ketiga $\left(\mathrm{H}_{5}\right)$ adalah untuk mengetahui apakah menutup $\left(\mathrm{X}_{4}\right)$ secara parsial berpengaruh signifikan terhadap keputusan pembelian kacamata pada Agung Optik di Kota Palu. Berdasarkan tabel di atas menunjukkan bahwa $\left(\mathrm{X}_{4}\right)$ memiliki nilai signifikan sebesar 0.000 . Artinya nilai tersebut $<$ dari taraf yang disyaratkan yaitu $\alpha=0.05$, maka dapat disimpulkan bahwa secara parsial menutup berpengaruh signifikan terhadap keputusan pembelian.

\section{Hasil Pengujian Hipotesis $X_{5}$ terhadap $Y$}

Hipotesis ketiga $\left(\mathrm{H}_{6}\right)$ adalah untuk mengetahui apakah tindak lanjut $\left(\mathrm{X}_{5}\right)$ secara parsial berpengaruh signifikan terhadap keputusan pembelian kacamata pada Agung Optik di Kota Palu. Berdasarkan tabel di atas menunjukkan bahwa $\left(\mathrm{X}_{5}\right)$ memiliki nilai signifikan sebesar 0.000 . Artinya nilai tersebut $<$ dari taraf yang disyaratkan yaitu $\alpha=0.05$, maka dapat disimpulkan bahwa secara parsial tindak lanjut berpengaruh signifikan terhadap keputusan pembelian.

Berdasarkan hasil pengujian serta analisis yang telah dilakukan pada penelitian ini membuktikan bahwa personal selling secara simultan berpengaruh signifikan terhadap keputusan pembelian kacamata pada Agung Optik di Kota Palu. Berdasarkan tabel rekapitulasi regresi linear berganda dapat dilihat pengaruh hasil uji determinasi Adjusted $R$ Square sebesar 0.818. Nilai tersebut dapat diartikan bahwa seluruh dimensi bebas yakni personal selling mempunyai konstribusi secara bersama-sama sebesar $81,8 \%$ terhadap variabel terikat yaitu terhadap keputusan pembelian kacamata pada Agung Optik di Kota Palu. Sedangkan sisanya $(100 \%-81,8 \%=18,2 \%)$, dipengaruhi oleh variabel lain yang tidak diteliti misalnya variabel harga, kualitas produk, dan lain-lain yang secara teori dan hasil-hasil penelitian sebelumnya berpengaruh terhadap keputusan pembelian.

Hasil penelitian ini sejalan dengan penelitian yang dilakukan oleh Tika (2016) yang menyatakan bahwa personal selling secara simultan berpengaruh signifikan terhadap keputusan pembelian PT Millenium Pharmacon Internasional Tbk Cabang Bandung, selain itu juga ada Anisatul (2016) yang menyatakan hasil penelitiannya yaitu personal selling berpengaruh signifikan terhadap keputusan pembelian Pada PT Asuransi Jiwasraya Jember, penelitian sebelumnya juga dilakukan oleh Sitorus (2014) menyatakan bahwa harga dan personal selling berpengaruh signifikan terhadap keputusan pembelian pada CV Sanfremy Pratama Medan.

Pendekatan merupakan tahap penjualan dimana tenaga penjual bertemu dengan pelanggan untuk pertama kali. Pendekatan adalah bagian yang penting bagi seorang penjual karena harus memperkenalkan dirinya sendiri, perusahaan yang diwakilinya dan produk atau jasa yang ditawarkan. Pendekatan yang dilakukan diawali dengan pembukaan yang positif untuk membangun kesan yang baik kepada konsumen. Pembukaan dapat diikuti dengan beberapa pertanyaan kepada konsumen untuk mengetahui apa yang dibutuhkan konsumen atau dengan menunjukan tampilan atau produk sampel (contoh produk) untuk menarik konsumen. Sikap keramahan tenaga penjual merupakan salah satu daya tarik bagi konsumen. Kesan yang lebih positif, maka ini merupakan awal yang baik bagi tenaga penjual untuk berinteraksi dengan calon konsumen.

Proses pendekatan yang dilakukan tenaga penjual dari Agung Optik yaitu tenaga penjual mencari calon pelanggan kemudian menilai karakter dari calon pelanggan tersebut, pada saat melakukan pendekatan kepada calon pelanggan tenaga penjual tidak langsung menawarkan produk-produk kacamata, tetapi mengajak berbicara calon pelanggan dengan masalah lain, setelah calon pelanggan merasa nyaman dengan pembicaraan, tenaga penjual baru memulai membuka pembicaraan masalah tentang produk kacamata. Cara menyapa dan komunikasi yang dilakukan tenaga penjual ini 
menyesuaikan dengan kondisi di lapangan.Pendekatan yang diterapkan oleh tenaga penjual tidak hanya dilakukan untuk menarik konsumen melakukan pembelian terhadap produk-produk kacamata, melainkan bagaimana menumbuhkan sikap yang positif mengenai produk kacamata tersebut di benak konsumen. Sikap yang positif terhadap produk-produk kacamata yang tertanam dalam benak konsumen akan mempengaruhi perilaku pembelian konsumen maupun perilaku konsumsi selanjutnya.

Hasil penelitian ini variabel pendekatan (X1) variabel yang memiliki nilai mean paling tinggi. Hal ini mengindikasikan bahwa konsumen lebih mempertimbangkan kesan pertama bertemu dan menyapa yang dilakukan oleh tenaga penjual, memberikan daya tarik kepada konsumen, dan menumbuhkan sikap yang positif kepada konsumen.

Berdasarkan hasil penelitian ini, mengungkapkan bahwa indikator-indikator yang digunakan untuk mengukur variabel pendekatan (X1) secara parsial berpengaruh signifikan terhadap keputusan pembelian kacamata pada Agung Optik. Penelitian yang telah dilakukan ini mendukung penelitian sebelumnya yang dilakukan oleh Indrayani (2014) yang hasilnya menunjukan bahwa pendekatan berpengaruh secara parsial terhadap keputusan pembelian produk Oriflame di Queneno Group Singaraja.

Presentasi dan demonstrasi merupakan tahap penjualan dimana tenaga penjual menguraikan penjelasan tentang fungsi dan manfaat produk kepada konsumen dan menunjukan bagaimana perusahaan dapat memberikan solusi atas masalah yang dihadapi konsumen. Menyampaikan penjelasan tentang produk kepada konsumen tenaga penjual perlu menekankan manfaat produk, seperti harga yang terjangkau, biaya perawatan yang ringan, dan beberapa keuntungan yang diperoleh konsumen.

Pada saat presentasi tenaga penjual membawa sampel produk (contoh produk) kacamata, ukuranukuran lensa, dan alat bantu lainnya untuk memperkenalkan kepada calon konsumen dan membentuk pemahaman sehingga akan membuat calon konsumen tertarik untuk membelinya. Tenaga penjual menunjukan sikap tidak hanya memahami produk yang ditawarkan tetapi tenaga penjual lebih mendengarkan kebutuhan calon pelanggan karena dari sini tenaga penjual dapat mengetahui kebutuhan kacamata yang diinginkan dari pelanggannya.

Hasil penelitian ini variabel presentasi dan demonstrasi (X2) variabel yang berpengaruh paling dominan terhadap keputusan pembelian kacamata pada Agung Optik. Hal ini berarti bahwa tenaga penjual sangat baik dalam presentasi karena sudah mampu memberikan penjelasan dan pemahaman tentang kejelasan kualitas dan kelebihan produk yang akan ditawarkan sehingga akan bermanfaat untuk konsumennya.

Berdasarkan hasil penelitian ini menunjukkan bahwa variabel presentasi dan demonstrasi (X2) secara parsial berpengaruh signifikan terhadap keputusan pembelian kacamata pada Agung Optik di kota Palu. Penelitian yang telah dilakukan ini mendukung penelitian sebelumnya yang dilakukan oleh Indrayani (2014), yang hasilnya menunjukan bahwa presentasi dan demonstrasi berpengaruh secara parsial terhadap keputusan pembelian Oriflame di Queneno Group Singaraja.

Penanganan keberatan merupakan proses tenaga penjual mengklarifikasi dan mengatasi keberatan pelanggan untuk membeli. Hampir setiap calon konsumen mungkin akan keberatan untuk melakukan pembelian dan sudah menjadi resiko. Keberatan dapat diungkapkan dengan pernyataan, pertanyaan atau bahkan dengan diam. Menangani keberatan calon konsumen, tenaga penjual dapat menanganinya secara positif dengan cara menanyakan apa saja hal-hal yang membuat calon konsumen merasa keberatan.

Tenaga penjual dapat memberikan jawaban atas pertanyaan calon konsumen dan memberikan penjelasan atas keberatan-keberatan tersebut dan apabila calon konsumen memberikan penolakan untuk membeli, tenaga penjual tetap memberikan nomor telepon atau identitas dari tenaga penjual 
kepada calon pelanggan, karena apabila calon pelanggan pada suatu saat membutuhkan dapat menghubungi dan akan menjadi lebih gampang bagi tenaga penjual untuk menindak lanjuti kembali, hal itu dapat membuat calon konsumen yang semula tidak tertarik untuk membeli secara tidak langsung akan memberikan dorongan untuk membeli kacamata tersebut karena merasa diperhatikan dan dilayani dengan baik.

Hasil penelitian ini, variabel penanganan keberatan memiliki nilai mean terendah, dan hal ini membuat tenaga penjual harus mempelajari keberatan calon konsumen dengan menggunakan pendekatan positif, mengklarifikasi dan meminta konsumen untuk menjelaskan keberatannya, menggunakan keberatan sebagai peluang untuk memberikan informasi lebih banyak dan mengubah keberatan menjadi alasan untuk membeli.

Berdasarkan hasil penelitian ini menunjukkan bahwa indikator-indikator yang digunakan untuk mengukur variabel penanganan keberatan (X3) secara parsial berpengaruh terhadap keputusan pembelian kacamata pada Agung Optik di kota Palu. Penelitian yang telah dilakukan ini mendukung penelitian sebelumnya yang dilakukan oleh Indrayani (2014) yang hasilnya menunjukan bahwa penanganan keberatan berpengaruh secara parsial terhadap keputusan pembelian Oriflame di Queneno Group Singaraja.

Menutup merupakan tahap penjualan dimana tenaga penjual meminta calon konsumen untuk membeli. Pertemuan tatap muka antara tenaga penjual dan calon konsumen, dimana terdapat pengkomunikasian fakta yang diperlukan untuk mempengaruhi keputusan pembelian atau menggunakan faktor psikologis dalam rangka membujuk dan memberikan keberanian pada waktu pembuatan keputusan pembelian dengan tujuan agar terjadi transaksi penjualan.

Pada saat menutup penjualan tenaga penjual melihat gerak fisik dari calon konsumen jika terlihat jenuh, tenaga penjual mengajak berbicara masalah lain jika calon konsumen sudah mulai nyaman, tenaga penjual menekankan kembali kelebihan produk yang ditawarkan agar calon konsumen lebih yakin dan tenaga penjual menanyakan kepada calon konsumen apakah berminat dengan tawaran produk kacamata yang ditawarkan dengan memberikan persetujuannya termasuk didalamnya adalah mengajukan pertanyaan, membuat komentar dan bertanya tentang harga, syarat pembayaran angsuran atau hal-hal terkait produk.

Tenaga penjual menanyakan apa yang hendak dipesan oleh konsumen harus pada waktu yang tepat yaitu pada saat calon konsumen sudah benar-benar memahami apa yang dikatakan tenaga penjual. Apabila tenaga penjual menanyakan pesanan saat pembeli masih berpikir dan kelihatan ragu, maka bisa membuat konsumen jadi tidak tertarik untuk membeli produknya. Begitupun sebaliknya, apabila penjualan tenaga penjual menjelaskan produknya dengan waktu yang lama, akan membuat calon konsumen merasa bosan untuk mendengarkan. Sehingga pada saat menutup penjualan merupakan waktu yang terpenting untuk meyakinkan konsumen dengan mencocokkan produk kacamata sesuai kebutuhan konsumen agar memutuskan membeli sehingga terjadi transaksi.

Berdasarkan hasil penelitian ini, menunjukkan bahwa indikator-indikator yang digunakan untuk mengukur variabel menutup (X4) berpengaruh signifikan terhadap keputusan pembelian kacamata pada Agung Optik di kota Palu. Penelitian yang telah dilakukan ini mendukung penelitian sebelumnya yang dilakukan oleh Indrayani (2014) yang hasilnya menunjukan bahwa menutup penjualan berpengaruh secara parsial terhadap keputusan pembelian Oriflame di Queneno Group Singaraja.

Tindak lanjut merupakan tahap penjualan dimana tenaga penjual melakukan tindak lanjut setelah melakukan penjualan untuk memastikan kepuasan konsumen dan mendorong pembelian ulang. Untuk mempertahankan loyalitas pelanggan, walaupun tenaga penjual mempunyai keterbatasan dalam menjangkau serta menemui calon konsumen, biasanya tenaga penjual mengkomunikasikan kepada pelanggan lewat telepon untuk memberikan layanan mengenai informasi produk-produk baru ataupun 
untuk memastikan kepuasan konsumen setelah membeli, hal ini dilakukan untuk mempertahankan pelanggan dalam waktu jangka panjang.

Ketika konsumen sudah yakin bahwa produk kacamata tersebut dapat memberikan manfaat yang mampu memuaskan kebutuhan mereka, konsumen cenderung akan menggunakan kembali produk kacamata tersebut dimasa yang akan datang. Adanya kecenderungan untuk melakukan pembelian tersebut di dasari oleh respon yang positif terhadap produk dari merek tersebut.

Hasil penelitian ini menunjukkan bahwa variabel tindak lanjut (X5) secara parsial berpengaruh signifikan terhadap keputusan pembelian kacamata pada Agung Optik di kota Palu. Penelitian yang telah dilakukan ini mendukung penelitian yang dilakukan sebelumnya oleh Indrayani (2014) yang hasilnya menunjukan bahwa tindak lanjut berpengaruh secara parsial terhadap keputusan pembelian Oriflame di Queneno Group Singaraja.

\section{PENUTUP}

Berdasarkan hasil penelitian yang telah dijabarkan, maka diperoleh kesimpulan mengenai pengaruh personal selling terhadap keputusan pembelian kacamata pada Agung Optik di Kota Palu, sebagai berikut:

1. Variabel personal selling yang terdiri dari pendekatan, presentasi dan demonstrasi, penanganan keberatan, menutup, dan tindak lanjut secara simultan atau serempak berpengaruh signifikan terhadap keputusan pembelian kacamata pada Agung Optik di Kota Palu.

2. Variabel pendekatan secara parsial berpengaruh signifikan terhadap keputusan pembelian kacamata pada Agung Optik di Kota Palu.

3. Variabel presentasi dan demonstrasi secara parsial berpengaruh signifikan terhadap keputusan pembelian kacamata pada Agung Optik di Kota Palu.

4. Variabel penanganan keberatan secara parsial berpengaruh signifikan terhadap keputusan pembelian kacamata pada Agung Optik di Kota Palu.

5. Variabel menutup secara parsial berpengaruh signifikan terhadap keputusan pembelian kacamata pada Agung Optik di Kota Palu.

6. Variabel tindak lanjut secara parsial berpengaruh signifikan terhadap keputusan pembelian kacamata pada Agung Optik di Kota Palu.

1. Bagi perusahaan, sebaiknya meningkatkan pelayanan terhadap konsumen dan tetap mempertahankan sikap ramah dan penghargaan kepada pelanggan dalam menghadapi sikap keberatan dari pelanggan dan berikan kesempatan kepada pelanggan untuk menyampaikan harapannya karena dari hasil penelitian variabel penanganan keberatan memiliki nilai mean terendah.

2. Bagi perusahaan, sebaiknya melakukan promosi melalui sosial media mengingat kurangnya promosi yang dilakukan. Promosi dalam sosial media dapat dilakukan untuk mengenalkan kepada masyarakat luas agar lebih menarik calon konsumen lebih banyak lagi dan lebih mempermudah mendapatkan informasi yang pelanggan cari secara online, sehingga pelanggan merasa lebih praktis.

3. Bagi penelitian selanjutnya, diharapkan dapat melakukan penelitian dengan menggunakan variabelvariabel lain yang dapat mempengaruhi keputusan pembelian produk kacamata, karena pada penelitian ini ditemukan masih ada faktor-faktor lain yang mempengaruhi keputusan pembelian. Dengan menggunakan faktor-faktor lain yang belum diteliti pada penelitian ini, mungkin akan lebih bermanfaat bagi perusahaan dan perkembangan ilmu pengetahuan mendatang. 


\section{REFERENSI}

Ghozali, I. 2013. Aplikasi Analisis Multivariat Dengan Program IBM SPSS, (7 ed). Semarang: Universitas Diponegoro.

Hermawan, Agus., 2012. Komunikasi Pemasaran, Jakarta: Erlangga.

Indrayani, Luh., 2014. Pengaruh Personal Selling Terhadap Keputusan Pembelian Produk Oriflame Di Queneno Group Singaraja, Skripsi, Jurusan Pendidikan Ekonomi Universitas Pendidikan Ganesha.

Kotler, Philip, dan Gary Armstrong., 2012. Principles Of Marketing, (14 ed.). New Jersey,USA: Pearson Prentice Hall.

Panjaitan, Tika Hapsahroni, 2016. Pengaruh Personal Selling Terhadap Keputusan Pembelian (Studi Kasus PT Millenium Pharmacon Internasional Tbk Cabang Bandung). E-proceeding of Applied Science, Vol.2, No.2, Agustus 2016, 448-457.

Sugiyono, 2012. Metode Penelitian Kuantitatif, Kualitatif, dan R\&D. Bandung: Alfabeta.

Sugiyono, 2014. Metode Penelitian Bisnis (Pendekatan Kuantitatif, Kualitatif, dan R\&D (18 ed). Bandung: Alfabeta.

Sugiyono, 2015. Metode Penelitian Kuantitatif, Kualitatif,dan Kombinasi (Mixed Methods). Bandung: Alfabeta.

Sitorus, Sunday Ade, 2014. Pengaruh Harga dan Personal Selling Terhadap Keputusan Pembelian Konsumen Pada CV Sanfremy Pratama Medan. Jurnal Informatika AMIK-LB, Vol. 2, No.2, 2014, 91-98.

Umah, Anisatul., 2016. Pengaruh Personal Selling Terhadap Keputusan Pembelian Pada PT. Asuransi Jiwasraya Jember, Skripsi, Fakultas Ilmu Sosial Dan Ilmu Politik Universitas Jember. 